\title{
Financial Performance Analysis of Banks with Topsis and Fuzzy Topsis Approaches
}

\author{
Yuksel Akay UNVAN* \\ Ylldirım Beyazıt University, Faculty of Management, 06760 Ankara, Turkey \\ Highlights \\ - This paper focuses on the criteria that affect the financial performance of banks. \\ - TOPSIS and Fuzzy TOPSIS methods are used for performance evaluation in the study. \\ - The results of TOPSIS and Fuzzy TOPSIS methods are similar.
}

\begin{tabular}{l} 
Article Info \\
\hline \\
Received: $01 / 05 / 2020$ \\
Accepted: $20 / 05 / 2020$ \\
Keywords \\
\hline Financial Performance \\
Banks \\
TOPSIS \\
Fuzzy TOPSIS
\end{tabular}

\section{INTRODUCTION}

Banks, which are important institutions of the money and financial markets, play a major role in the economy. Positive or negative events occured in the banking sector also affect other sectors through banking activities. Banks are profit-making companies. Technological developments, globalization and competition require banks to use their resources effectively. Therefore, effective and efficient operation of banks is one of the most important issues of the money and financial markets. Effective operation of banks that are at the center of the economy, and measuring and evaluating their performances both determine their role in the sector and have strategic importance on process management of the country's economy. Because, unlike other economic sectors, the banking sector assumed the role of financial intermediation, which determines the resource allocation. For this purpose, an analysis of efficiency and productivity requirements is needed in order to conduct the performance analysis of the banking sector.

The reasons for measuring and evaluating banks' performance are listed as follows [1]:

- To measure the level of customer satisfaction, to receive feedback on the services offered to customers.

- To determine its position by making comparative analysis with other banks.

- To determine whether the organization and its shareholders are successful. 
- To make sure that the decision is based entirely on real data, without making assumptions or conveying personal thoughts.

- Finding and addressing problems that are troublesome in the organization.

- To identify the regions that are open to development within the institution and to determine the advantages of these regions.

Banks' financial performance is evaluated according to various criteria. The correct and effective evaluation of financial performances is based on the correct selection of criteria and methods. Accurate analysis of financial performances will increase the profitability of banks by reducing their risky transactions. Determining the performance measurement criteria and features plays an important role in the analysis of the performances in achieving the targets of the banks. It is stated that the performance criteria should have the following features [2]:

- Performance factors should be measured independently.

- Precautions should be meaningful and understandable for the user.

- The measures are consistent with the bank's strategic goals.

- The measures are consistent with the bank's competitive strategies.

- Measurement methods should be robust and reliable.

- Performance measures should be re-evaluated and changed if necessary.

- Measures should be reviewed and accepted by all people from their own perspectives.

A bank that has a high performance compared to a rate used may perform poorly compared to another. After the 2008 global financial crisis, uncertainty has increased worldwide, so the use of fuzzy methods can provide better results under these conditions. Since the risk, uncertainty and competition continue to increase in the banking sector, fuzzy techniques are used and performance measurements can provide more reliable and sensitive results. In the analysis made using fuzzy approaches, it provides a more accurate and reliable analysis of financial rates that change over the years. Therefore, in this study, the TOPSIS method is included in the fuzzy TOPSIS method.

According to the report of the Banking Regulation and Supervision Agency (BRSA) dated January 2020, there are 51 banks. 6 of these banks operate as Participation Bank, 32 of them as Deposit Bank and 13 of them as Development and Investment Bank. When looked at the employment size provided by these banks, the deposits collected and the loans extended, it is understood how important the banking system is.

This study discussed the criteria which affect banks' financial performance and explained the determined criteria in detail. According to the report obtained from the Banking Association of Turkey for the period 2014-2018, the first seven banks were listed in total assets and a performance assessment was made by using TOPSIS and Fuzzy TOPSIS methods. The following rates were used to determine TOPSIS scores in the study; debt / total capital assets, total loans / total assets, loans / total loans, fixed assets / total asset(s), liquid assets / total assets, liquid asset / total asset, liquid asset / short-term liabilities, net profit (loss) over a term, net profit / equity period, net interest income / total asset ratios.

The reasons for performance evaluation of banks, potential characteristics of the metrics used to assess performance, and details on this research were provided in the first part of the report. The second part of the study clarified research on bank performance assessment and the decision-making processes utilized by various criteria. The third section outlined the parameters used in the assessment of financial results. In the fourth section, the TOPSIS and dynamic TOPSIS approaches were explained in the multi-criteria decisionmaking methods employed in the analysis. In the fifth segment, using the data from the Association of Banks of Turkey, TOPSIS and fuzzy TOPSIS methods were implemented. Finally, the results obtained were discussed. 


\subsection{Literature Review}

In this section of the study, the methods and studies of decisions assessing banks' financial performance will be shared by multiple criteria. In the literature, there are numerous studies assessing the financial performance of banks using multi-criteria decision models. The need for these studies is slowly growing due to technological advances, globalization and increased competition. Ratio analysis is one of the most common approaches used for financial performance evaluations. Tozum conducted ratio analysis measurements [3]. Li, Liu, Liu and Whitmore contrasted the financial results of Chinese banks with nine financial ratios [4]. By using the balance sheets, Guven and Persentili have built a linear model for programming banks' performance assessment [5]. The performance evaluation models for the measure of failures were developed by Zopounidis, Pouliezos, Yannacopoulo and Siskos, Zopounidis and Pouliezas [6-7].

In study, Ecer compared the financial performance of private Turkish banks within the 2008-2011 period using the Gray Relational Analysis approach [8]. The CAMELS rating is another way to assess banking efficiency. Six components are included for the CAMELS rating; they are sensitive to equity, asset quality, management, profitability, liquidity and market. Dincer et al. assessed national, private and foreign banks' financial output with CAMELS in 2008 [9]. Guneysu et al. were used AHP and Gray Relational Analysis method in order to find out financial performance of commercial banks operating in the Turkish banking system in 2010-2014 period [10]. In his study, Tezergil evaluated the financial performance of deposit banks operating in the Turkish banking sector using the VIKOR method [11].

Altunoz evaluated the financial performances of 12 banks traded in BIST in the period 2007-2016 with fuzzy MOORA and fuzzy AHP methods [12]. Gunay and Gunay evaluated the financial performance of 15 commercial banks operating in Turkey for the period 2012-2016 by using the ELECTRA and TOPSIS methods [13]. The knowledge and perception of bank employees by using CAMELS ranking was investigated by Mittal and Dhade[14].

Data Envelopment Analysis (DEA) is another significant tool for assessing banks' financial efficiency. This method is used for measuring bank branch performance. Demir and Astarcioglu assessed the Turkish commercial DEA banks, taking their total business, interest revenues and expenses, expanded loans and non-interest revenues, and expenses into account[15]. The effect of bank growth on selected financial ratios between 1989 and 1999 was analyzed with the DEA methods by Mercan, Reisman, Yolalan and Emel [16]. Lin and Zhang have examined the impact of property on bank performance via DEA [17]. Other certain DEA studies include Bauer, Berger, Ferrier and Humphrie [18], Parkan and Wu [19], Denizer et al.[20], Isik, Uysal, and Meleke [21]. DEA tests have also been carried out in the literature. Demirguc-Kunt and Huizinga have implemented several new variables which had not previously been used and observed their effects [22]. In contrast with the calculation of bank results, Thanasseoulis, Boussofiane, and Dyson used DEA and ratio analysis and reported that these approaches were not synonymous [23].

The classical analysis hierarchy process (AHP) is another tool for assessing banks' financial efficiency. A large number of studies used the AHP method. These studies were based on performance determination factors, performance assessment of potential suppliers, credit evaluation analysis and production department performance measurement [24-26].

In the calculation of bank results, Frei and Harker used AHP as an alternative to DEA [27]. In this study the correlation between financial performance and business performance was examined. In the evaluation of the loan risk with financial and non-financial performance metrics, Yurdakul and Ic evaluated the bank's success[28] using AHP. Albayrak and Erensal examined the results of Turkish banks using fuzzy AHP [29] for financial and non-financial performance parameters.

In order to assess and analyze bank efficiency [30-32], scientists often use multi criteria decision-making methods. In the light of bilateral relations between banks and the manufacturing companies using AHP in Turkey, Yurdakul and Ic investigated the company's reliability values [28]. Based on their financial and non-financial performance, businesses earn a general reliability ranking. Models based on AHP are often chosen because they integrate business banks' financial analyses with political, organizational, financial, non-financial, qualitative, and quantitative details. Secme et al. tested five commercial banks operating in 
Turkey's financial and non-financial results. They used the AHP and TOPSIS models for determining weight and measurement of performance [33].

\section{MATERIAL AND METHODS}

\subsection{Financial Ratios}

This section clarified the ratio of revenue and cost ratios, productivity, liquidity, quality of asset, balance sheet, and capital structure. While determining the financial ratios used in the study, expert opinions and studies were taken into consideration. Therefore, the financial ratios that can evaluate the financial performance of the bank in the most accurate way were selected.

\section{Balance Sheet and Capital Structure Ratio}

The balance sheet and the ratios of capital structure indicate that international resources are associated with their own resources. These rates demonstrate how banks financing utilizes their own and external capital.

K1: This ratio is obtained by dividing banks' equity by their total assets. It is the ratio that shows to what extent it finances its assets with its own capital.

\section{Asset Ratios}

Asset quality ratios show the rate at which banks attribute their resources to fixed assets, the structure of loans and whether there is a problem with their return.

K2: This rate shows the loan ratio in total assets and affects the degree of profitability.

K3: This ratio shows the ratio of non-performing loans to total loans.

K4: It shows the ratio of fixed assets in assets.

\section{Liquidity Ratios}

Liquidity ratios show the ability to pay. It shows the relationship between the assets that can be converted into money and their short-term debts.

K5: This ratio shows the liquid assets ratio of banks in total assets.

K6: It is found by dividing the total current assets by a total of short term liabilities. This rate measures the bank's ability to pay its short-term debts.

\section{Profitability Ratios}

These rates are used to measure the success of the banks as a result of their performances and to evaluate whether the bank has achieved sufficient profitability.

K7: This ratio is found by dividing net profit by total assets and is used to measure how efficiently assets are used.

K8: This ratio is found by dividing net profit by total equity and is used to measure how efficiently assets are used.

\section{Income Expense Structure Ratios}

These rates indicate which income and expense items the bank receives are affected by and which items are predominant in their total income and expenses.

K9: This ratio shows the net interest income in total assets.

K10: This rate shows the interest income in total operating income. 


\subsection{Topsis Method}

The TOPSIS method is a method which is put forward by Chen and Hwang with reference to the works of Hwang and Yoon. [34-35]. As stated before, the TOPSIS method is one of the multi-criteria decision making methods. Using the method, alternative options should be compared according to certain criteria and between the maximum and minimum values that the criteria can take, according to the ideal situation [36]. Alternative number $\mathrm{n}$, multi-criteria decision making problem with $\mathrm{m}$ criteria can be shown with $\mathrm{n}$ points in m-dimensional space [37]. Hwang and Yoon developed the TOPSIS method, based on the assumption that the solution alternative will be the shortest distance to the positive ideal solution point and the farthest distance to the negative-ideal solution point [35]. The stages of the TOPSIS method can be expressed as follows.

\section{STEP 1: Creating a Decision Matrix}

Alternatives are placed in rows in the decision matrix and criteria are placed in columns. Matrix A created by the decision maker is the initial matrix [38]

$$
A_{i j}=\left[\begin{array}{cccc}
a_{11} & a_{12} & \ldots & a_{1 n} \\
a_{21} & a_{22} & \cdots & a_{2 n} \\
\cdot & \cdot & & \cdot \\
\cdot & \cdot & & \vdots \\
a_{m 1} & a_{m 2} & \ldots & a_{m n}
\end{array}\right] .
$$

STEP 2: Creating the Standard Decision Matrix

The alternatives in the decision matrix are listed in the form of $\left(a_{1} \ldots a_{n}\right)$ one after the other, and each criterion is shaped according to different alternatives and sorted as properties $\left(y_{1} \ldots y_{n k}\right)$ [39]

$$
r_{i j}=\frac{a_{i j}}{\sqrt{\sum_{k=1}^{m} a_{k j}^{2}}} \quad \begin{aligned}
& i=1,2 \ldots, n \\
& j=1,2 \ldots, k .
\end{aligned}
$$

\section{STEP 3: Creating the Weighted Standard Decision Matrix}

The weight values $\left(w_{i}\right)$ associated with the evaluation factors are determined. Weights are determined by the importance of the criteria. The sum of the determined weight values should be one [40]

$\sum_{i=1}^{n} w_{i}=1$.

The weighted standard decision matrix $(\mathrm{V})$ is created by multiplying the weight value $\left(w_{i}\right)$ of the elements in each column of the standard decision matrix $(\mathrm{R})$ [41]

$$
V_{i j}=\left[\begin{array}{cccc}
w_{1} r_{11} & w_{2} r_{12} & \ldots & w_{n} r_{1 n} \\
w_{1} r_{21} & w_{2} r_{22} & \ldots & w_{n} r_{2 n} \\
\cdot & \cdot & & \cdot \\
\cdot & \cdot & & \vdots \\
w_{1} r_{m 1} & w_{2} r_{m 2} & \ldots & w_{n} r_{m n}
\end{array}\right]
$$

STEP 4: Creating Positive Ideal $\left(A^{*}\right)$ and Negative Ideal $\left(A^{-}\right)$Solutions

The value weights are chosen according to whether they are maximization or minimization [42] 


$$
\begin{aligned}
& A^{*}=\left\{v_{1}^{*}, v_{2}^{*}, \ldots, v_{n}^{*}\right\} \\
& A^{-}=\left\{v_{1}^{-}, v_{2}^{-}, \ldots, v_{n}^{-}\right\} .
\end{aligned}
$$

STEP 5: Calculation of Separation of Measurements

The distance approach is used to find possible deviations from the ideal solution for each decision point assessment. Deviation values are stated as ideal separation $\left(S_{i}^{*}\right)$ and negative ideal separation $\left(S_{i}^{-}\right)$measure [43]

$$
\begin{aligned}
& S_{i}^{*}=\sqrt{\sum_{j=1}^{n}\left(v_{i j}-v_{j}^{*}\right)^{2}} \\
& S_{i}^{-}=\sqrt{\sum_{j=1}^{n}\left(v_{i j}-v_{j}^{-}\right)^{2}} .
\end{aligned}
$$

STEP 6: Calculating Relative Affinity to the Ideal Solution

The estimation of each value is verified with the correct solution using ideal and negative discriminatory steps. This test refers to the negative ideal measure of discrimination to the overall measure of discrimination. As a consequence of ideal solution 1, the decision point shows that the ideal solution is close to the ideal solution and 0 means that the ideal solution is negative [44]

$$
C_{i}^{*}=\frac{S_{i}^{-}}{S_{i}^{-}+S_{i}^{*}} \text {. }
$$

\subsection{Fuzzy Set Theory and Fuzzy Numbers}

In his thesis "Fuzzy Sets," which he wrote on the paper "Knowledge and Control", in 1965, the Azerbaijani scientist Lutfu Askerzade, also referred in Zadeh, developed Fuzzy logic. In this research, Zadeh identified fluid clusters as categorized and permanent clusters. In comparison to binary logic, the membership values of the components of a group range from 0 to 1 [45]. Fuzzy refers to details that is complete and wrong. In other words, Fuzzy is mainly about verbal knowledge. The idea of "fuzzy logic" is synonymous with recognizing the confusion of daily and professional lives and using it to solve problems. In the case of fear, Fuzzy Logic more closely represents people's mental job processes than classic logic. It was claimed to have an important role in human thoughts in some classifications, such as recognition, communication with knowledge, and abstraction. But mathematical expressions can't be used in these classifications[45]. Fuzzy logic was passed to systems and with different models participated in the decision-making process. Fuzzy logic uses its mathematical base and fuzzy set theory, which is the most basic concept, to make these models. Fuzzy set theory was created by L. Zadeh inspired by real life. Fuzzy sets emerge as a very important tool and mathematical expression in modeling fuzzy logic. Fuzzy set theory helps to measure uncertainty through subjective judgments [46].

A fuzzy set $\tilde{A}[0,1]$ is a set expressed by a function defined in the closed range [47]

$$
\mu_{\tilde{A}}: \quad E \rightarrow[0,1] .
$$

The real-number values form specific and multiple fuzzy sets. Fuzzy sets express the unknown, undefined and estimated values by means of fuzzy numbers. Numbers of fuzzy are numbers with verbal phrases like roughly and nearly. The triangular and trapezoidal fuzzy numbers are most commonly used in applications. A triangle in the form of $(a, b, c)$, is the lowest value to the left of a fuzzy number, $b$ is the most suitable value and $\mathrm{c}$ is the highest limit to the right. The Fuzzy number membership function is as follows

$$
\mu_{A(x)}=\left\{\begin{array}{cc}
0, & x \leq a \\
\frac{x-a}{b-a}, & a \leq x \leq b \\
\frac{c-x}{c-b}, & b \leq x \leq c \\
0, & x \geq c
\end{array} .\right.
$$


In fuzzy sets, membership function is determined to identfy and show the degree of belonging of an element to fuzzy sets. The cluster elements within a closed range are assigned values to this function $[0,1]$. This value shows how much an element is in the fuzzy package. The properties of the cluster, in other words, indicate the carrying power. Fuzzy sets with different membership functions appear to be expressed mathematically. Although the most used membership functions are triangular and trapezoid, it is seen that different membership functions such as Sigmoid, Gauss (Bell Curve), S-shaped and Z-shaped are also used.

In fuzzy sets, mathematical operations can be performed as in classical sets. Two positive fuzzy numbers $\mathrm{A}$ and $\mathrm{B}$ are given as $\tilde{A}=\left(a_{1}, a_{2}, a_{3}\right)$ and $\tilde{B}=\left(b_{1}, b_{2}, b_{3}\right)$ [48]:

$$
\begin{aligned}
& \tilde{A}+\tilde{B}=\left(a_{1}+b_{1}, a_{2}+b_{2}, a_{3}+b_{3}\right) \\
& \tilde{A}-\tilde{B}=\left(a_{1}-b_{1}, a_{2}-b_{2}, a_{3}-b_{3}\right) \\
& \tilde{A} * \tilde{B}=\left(a_{1} * b_{1}, a_{2} * b_{2}, a_{3} * b_{3}\right) \\
& \tilde{A} / \tilde{B}=\left(a_{1} / b_{1}, a_{2} / b_{2}, a_{3} / b_{3}\right) \\
& c * \tilde{A}=\left(c * a_{1}, c * a_{2}, c * a_{3}\right) \\
& \tilde{A}^{-1}=\left(\frac{1}{a_{1}}, \frac{1}{a_{2}}, \frac{1}{a_{3}}\right) .
\end{aligned}
$$

\subsection{Fuzzy Topsis}

It provides the decision making in fuzzy environments by enabling quantitative and qualitative variables that affect fuzzy TOPSIS decision problems, which are among the fuzzy multi-criteria decision making methods, to participate in the solution process. Fuzzy TOPSIS method developed by Chen will be applied in the study. [49]. Fuzzy TOPSIS method is an effective tool for individual and group decision making When it comes to group decision-making, solution is performed by combining the decisions of all decision makers. The first step in the application of the method is to create a decision matrix by evaluating the decision alternatives according to the criteria determined as a result of the previous studies.

Step 1: In a group with $\mathrm{K}$ decision makers, $w_{j}^{K}$ is affected by $\mathrm{j}$. The importance weight of the decision criterion is calculated with the formula below [49]

$\widetilde{W}_{i j}=\frac{1}{K}\left[\widetilde{w}_{i j}^{1}+\widetilde{w}_{i j}^{2}+\cdots+\widetilde{w}_{i j}^{K}\right]$.

Step 2: In a group with $\mathrm{K}$ decision makers, the importance weight of the $\mathrm{i}^{\text {th }}$ alternative of $X_{i j}^{K}$ in the decision problem is calculated by the formula below [49]:

$\tilde{X}_{i j}=\frac{1}{K}\left[\tilde{x}_{i j}^{1}+\tilde{x}_{i j}^{2}+\cdots+\tilde{x}_{i j}^{K}\right]$.

Step 3: The decision matrix and criterion weights matrix of a multi-criteria decision making problem can be shown as follows:

$$
\widetilde{W}=\left[\widetilde{w}_{1}, \widetilde{w}_{2}, \ldots, \widetilde{w}_{n}\right]
$$




$$
\widetilde{D}=\begin{gathered}
A_{1} \\
A_{2} \\
\vdots \\
A_{m}
\end{gathered}\left[\begin{array}{cccc}
\tilde{x}_{11} & \tilde{x}_{12} & \ldots & \tilde{x}_{1 n} \\
\tilde{x}_{21} & \tilde{x}_{22} & \ldots & \tilde{x}_{2 n} \\
\cdot & \cdot & & \cdot \\
\tilde{x}_{m 1} & \tilde{x}_{m 2} & \ldots & \vdots \\
\tilde{x}_{m n}
\end{array}\right]
$$

$\widetilde{D}$ is expressed as the fuzzy decision matrix and $\widetilde{W}$ is expressed as the fuzzy weights matrix. The elements and weights of the matrix are shown as $\tilde{x}_{i j}=\left(a_{i j}, b_{i j}, c_{i j}\right)$ and $\widetilde{w}_{j}=\left(w_{j 1}, w_{j 2}, w_{j 3}\right)$ [49].

Step 4: After the fuzzy decision matrix is created, the normalized fuzzy decision matrix is calculated. This matrix is represented as follows:

$$
\begin{array}{ll}
\tilde{r}_{i j}=\left(\frac{a_{i j}}{c_{j}^{*}}, \frac{b_{i j}}{c_{j}^{*}}, \frac{c_{i j}}{c_{j}^{*}}\right), & a_{j}^{-}=\max _{i j}, \forall_{j} \in B \\
\tilde{r}_{i j}=\left(\frac{a_{j}^{-}}{a_{i j}}, \frac{a_{j}^{-}}{b_{i j}}, \frac{a_{j}^{-}}{c_{i j}}\right), & a_{j}^{-}=\operatorname{mina}_{i j}, \forall_{j} \in C .
\end{array}
$$

The normalized fuzzy decision matrix, as can be seen in the formula, is determined by dividing the values for the decision problem by the highest in the column to which every variable in the decision matrix belongs. It is determined on the basis of the smallest elements of each column when normalizing the cost parameters.

Each fuzzy number is given within the range $[0,1]$ in a normalized matrix. The weighted normalized decisions matrix is calculated by taking into account the significance weight of each criterion after calculating the normalized decision matrix.

The weighted normalized decision matrix is shown as follows:

$$
\tilde{V}=\left[\tilde{v}_{i j}\right]_{m x n} \quad \begin{array}{ll}
i=1,2, \ldots, m \\
j=1,2, \ldots, n .
\end{array}
$$

The values of each element $\tilde{v}_{i j}$ of the matrix $\tilde{V}$ are calculated by the formula:

$\tilde{v}_{i j}=\tilde{r}_{i j} \widetilde{w}_{j}$

In order to find the weighted normalized fuzzy decision matrix, the normalized fuzzy decision matrix is multiplied by the fuzzy weights matrix. In this case, the calculated $\mathrm{V}$ matrix is shown as follows:

After calculating the weighted normalized fuzzy decision matrix $\mathrm{V}$, the fuzzy positive ideal solution $A^{*}$ and fuzzy negative ideal solution $A^{-}$must be calculated

$$
\begin{array}{lrl}
A^{*} & =\left\{v_{1}^{*}, v_{2}^{*}, \ldots, v_{n}^{*}\right\} & i=1,2, \ldots, m \\
A^{-}=\left\{v_{1}^{-}, v_{2}^{-}, \ldots, v_{n}^{-}\right\} & j=1,2, \ldots, n .
\end{array}
$$

Here is accepted as $\tilde{v}_{i j}^{*}=(1,1,1)$ and $\tilde{v}_{i j}^{-}=(0,0,0)$ [50].

Step 7: Calculating the distance of alternatives to the positive ideal and negative ideal solution point

For each alternative, the distances to the positive and negative ideal solution points are calculated with the following formulas

$$
\begin{array}{ll}
d_{i}^{*}=\sum_{j=1}^{n} d\left(\tilde{v}_{i j}, \tilde{v}_{j}^{*}\right) & i=1,2, \ldots, m \\
d_{i}^{-}=\sum_{j=1}^{n} d\left(\tilde{v}_{i j}, \tilde{v}_{j}^{-}\right) & i=1,2, \ldots, m .
\end{array}
$$


In the method, finally, the closeness of the alternatives to the ideal solution is calculated. For this, Vertex method, which is used to calculate the distance from one of the fuzzy numbers, is used. The distance between two triangle fuzzy numbers $\tilde{A}=\left(m_{1}, m_{2}, m_{3}\right)$ and $\tilde{B}=\left(n_{1}, n_{2}, n_{3}\right)$, is calculated by the following formula according to the vertex method:

$d_{v}(\widetilde{m}, \tilde{n})=\sqrt{\frac{1}{3}\left[\left(m_{1}-n_{1}\right)^{2}+\left(m_{2}-n_{2}\right)^{2}+\left(m_{3}-n_{3}\right)^{2}\right]}$.

Proximity coefficients should be calculated in order to choose between alternatives or evaluate alternatives. The proximity coefficient is calculated for each alternative using the formula below [51].

Step 8: Calculating proximity coefficients and sorting alternatives

In the next step, the proximity coefficient $C C_{i}$ is calculated for each alternative. The proximity coefficient is in the range $[0,1]$ and the alternatives are listed with the help of this coefficient. The equation for calculating the proximity coefficient is given below:

$C C_{i}=\frac{d_{i}^{-}}{d_{i}^{*}+d_{i}^{-}}, \quad i=1,2, \ldots, m$.

The decision is to order the alternatives according to the $\mathrm{CC}_{\mathrm{i}}$ coefficient of proximity values. As the proximity coefficient reaches 1 the value of the alternative is approaching the fuzzy positive ideal solution, and as the proximity coefficient is approaching the value 0 . When the coefficient of proximity is 1 , the value of the alternative equals the fuzzy positive solution, and when the coefficient of proximity is 0 , the value of the alternative equals the fuzzy negative ideal solution [52].

\subsection{Empirical Study}

In this section, the performance assessment of the first seven banks in terms of asset size was compared according to reports obtained from the Banks Association of Turkey between 2014 and 2018. When the previous studies were examined and expert opinion was taken, it was decided to select the asset size as the ranking criteria for banks. Also the reason for using asset sizes in determining banks is because asset size clearly reflects the size of banks. In addition, when the sequential asset size of 51 banks in the data set is analyzed, there is a sharp decline after the $7^{\text {th }}$ bank. Therefore, 7 banks with the highest asset size were chosen in the study. Table 1 displays the banks used in this analysis. Moreover, the descriptive statistics of the criteria determined is given in Table 2 .

Table 1. Banks used in this study according to reports received from the Banks Association of Turkey

\begin{tabular}{|l|c|}
\hline Bank & Code \\
\hline Akbank T.A.Ş. (AB) & B1 \\
\hline Türkiye Cumhuriyeti Ziraat Bankası A.Ş. (ZB) & B2 \\
\hline Türkiye Garanti Bankası A.Ş. (GB) & B3 \\
\hline Türkiye Halk Bankası A.Ş. (HB) & B4 \\
\hline Türkiye İş Bankası A.Ş. (IB) & B5 \\
\hline Türkiye Vakıflar Bankası T.A.O. (VB) & B6 \\
\hline Yapı ve Kredi Bankası A.Ş. (YKB) & B7 \\
\hline
\end{tabular}


Table 2. Descriptive statistics of the criteria

\begin{tabular}{|c|c|c|c|c|}
\hline & Mean & $\begin{array}{l}\text { Std. } \\
\text { Deviation }\end{array}$ & Minimum & Maximum \\
\hline \multicolumn{5}{|l|}{ Balance Sheet and Capital Structure Ratio } \\
\hline EQUITY / TOTAL ASSETS & 0,019147 & 0,005468 & 0,012171 & 0,026439 \\
\hline \multicolumn{5}{|l|}{ Asset Ratios } \\
\hline TOTAL LOANS / TOTAL ASSETS & 0,631065 & 0,034932 & 0,569991 & 0,666317 \\
\hline NON-PERFORMING LOAN/TOTAL LOANS & 0,026985 & 0,009712 & 0,015585 & 0,038089 \\
\hline FIXED ASSET / TOTAL ASSETS & 0,007882 & 0,00507 & 0,004187 & 0,018916 \\
\hline \multicolumn{5}{|l|}{ Liquidity Ratios } \\
\hline LIQUID ASSET / TOTAL ASSET & 0,010627 & 0,00414 & 0,00529 & 0,017364 \\
\hline LIQUID ASSET / SHORT TERM LIABILITIES & 2,051874 & 2,354894 & 0,09773 & 6,696827 \\
\hline \multicolumn{5}{|l|}{ Profitability Ratios } \\
\hline $\begin{array}{l}\text { NET PROFIT FOR THE PERIOD / TOTAL } \\
\text { ASSETS }\end{array}$ & 0,012325 & 0,002959 & 0,008419 & 0,016698 \\
\hline $\begin{array}{l}\text { NET PROFIT FOR THE PERIOD / TOTAL } \\
\text { EQUITY }\end{array}$ & 1,357116 & 0,834774 & 0,774572 & 3,156611 \\
\hline \multicolumn{5}{|l|}{ IncomeExpenseStructure Ratios } \\
\hline NET INTEREST INCOME / TOTAL ASSET & 0,032432 & 0,001926 & 0,029399 & 0,034761 \\
\hline $\begin{array}{l}\text { NET INTEREST INCOME / TOTAL } \\
\text { OPERATING INCOME }\end{array}$ & 0,70909 & 0,049649 & 0,662617 & 0,80311 \\
\hline
\end{tabular}

\section{Analysis of Financial Performance of Banks by Topsis Method}

Firstly, the decision matrix is created. The decision matrix created for 2014 is given in Table 3.

Table 3. Criteria decision matrix for 2014

\begin{tabular}{|l|l|l|l|l|l|l|l|l|l|l|}
\hline & & & & & Criteria & & & & & \\
\hline Banks & K1 & K2 & K3 & K4 & K5 & K6 & K7 & K8 & K9 & K10 \\
\hline B1 & 0,0206 & 0,6124 & 0,0185 & 0,0042 & 0,0147 & 6,6968 & $-0,0121$ & $-0,8234$ & 0,0337 & 0,7060 \\
\hline B2 & 0,0258 & 0,5700 & 0,0193 & 0,0189 & 0,0174 & 2,2002 & 0,0134 & 0,7746 & 0,0348 & 0,8031 \\
\hline B3 & 0,0175 & 0,6095 & 0,0247 & 0,0062 & 0,0090 & 3,4275 & 0,0137 & 1,5325 & 0,0340 & 0,6967 \\
\hline B4 & 0,0171 & 0,6465 & 0,0368 & 0,0076 & 0,0053 & 0,0977 & $-0,0167$ & $-3,1566$ & 0,0329 & 0,7435 \\
\hline B5 & 0,0264 & 0,6532 & 0,0156 & 0,0080 & 0,0110 & $-0,6328$ & 0,0133 & 1,2121 & 0,0314 & 0,6626 \\
\hline B6 & 0,0143 & 0,6595 & 0,0381 & 0,0045 & 0,0093 & 0,8004 & $-0,0086$ & $-0,9221$ & 0,0294 & 0,6649 \\
\hline B7 & 0,0122 & 0,6663 & 0,0359 & 0,0058 & 0,0078 & 0,5076 & $-0,0084$ & $-1,0786$ & 0,0309 & 0,6868 \\
\hline
\end{tabular}

In the next stage, the normalization of the decision matrix is created. Then the weighted decision matrix is created with the use of weights. In this study, the weight values of each criterion were determined as 0.1 . The weighted decision matrix is obtained by multiplying the weights by the normalized decision matrix. The weighted decision matrix for 2014 is given in Table 4. 
Table 4. Weight values of ratios

\begin{tabular}{|l|r|}
\hline Rate & Weight \\
\hline EQUITY / TOTAL ASSETS & 0,1 \\
\hline TOTAL LOANS / TOTAL ASSETS & 0,1 \\
\hline NON-PERFORMING LOAN/TOTAL LOANS & 0,1 \\
\hline FIXED ASSET / TOTAL ASSETS & 0,1 \\
\hline LIQUID ASSET / TOTAL ASSET & 0,1 \\
\hline LIQUID ASSET / SHORT TERM LIABILITIES & 0,1 \\
\hline NET PROFIT FOR THE PERIOD / TOTAL ASSETS & 0,1 \\
\hline NET PROFIT FOR THE PERIOD / TOTAL EQUITY & 0,1 \\
\hline NET INTEREST INCOME / TOTAL ASSET & 0,1 \\
\hline NET INTEREST INCOME / TOTAL OPERATING INCOME & 0,1 \\
\hline TOTAL & 1 \\
\hline
\end{tabular}

Then the minimum and maximum values are determined by the weighted decision matrix. The minimum and maximum values is given in Table 5 .

Table 5. Weighted decision matrix

\begin{tabular}{|l|l|l|l|l|l|l|l|l|l|l|}
\hline & & & & & Criteria & & & & & \\
\hline Banks & K1 & K2 & K3 & K4 & K5 & K6 & K7 & K8 & K9 & K10 \\
\hline B1 & 0,0154 & 0,0139 & 0,0098 & 0,0076 & 0,0197 & 0,0511 & 0,2274 & 0,0335 & 0,0148 & 0,0142 \\
\hline B2 & 0,0193 & 0,0129 & 0,0102 & 0,0343 & 0,0233 & 0,0168 & $-0,2532$ & $-0,0315$ & 0,0153 & 0,0162 \\
\hline B3 & 0,0131 & 0,0138 & 0,0131 & 0,0112 & 0,0120 & 0,0262 & $-0,2584$ & $-0,0623$ & 0,0150 & 0,0140 \\
\hline B4 & 0,0128 & 0,0146 & 0,0195 & 0,0138 & 0,0071 & 0,0007 & 0,3143 & 0,1282 & 0,0145 & 0,0150 \\
\hline B5 & 0,0197 & 0,0148 & 0,0083 & 0,0145 & 0,0148 & $-0,0048$ & $-0,2504$ & $-0,0492$ & 0,0138 & 0,0133 \\
\hline B6 & 0,0106 & 0,0149 & 0,0202 & 0,0081 & 0,0125 & 0,0061 & 0,1618 & 0,0375 & 0,0130 & 0,0134 \\
\hline B7 & 0,0091 & 0,0151 & 0,0190 & 0,0105 & 0,0105 & 0,0039 & 0,1585 & 0,0438 & 0,0136 & 0,0138 \\
\hline
\end{tabular}

After determining the minimum and maximum values, the banks' performance scores and rankings are determined. The bank performance score for 2014-2018 is given in Table 6.

Table 6. Minimum and maximum values

\begin{tabular}{|r|r|}
\hline A* & A- \\
\hline 0,019726 & 0,009081 \\
\hline 0,015084 & 0,012903 \\
\hline 0,020164 & 0,008251 \\
\hline 0,034283 & 0,007588 \\
\hline 0,023341 & 0,007111 \\
\hline 0,051131 & $-0,00483$ \\
\hline 0,314308 & $-0,25843$ \\
\hline 0,128244 & $-0,06226$ \\
\hline 0,015312 & 0,01295 \\
\hline 0,01618 & 0,013349 \\
\hline
\end{tabular}


Table 7. 2014-2018 Bank performance score

\begin{tabular}{|r|r|r|r|r|}
\hline Banks & \multicolumn{1}{|c|}{$S_{i}^{*}$} & \multicolumn{1}{c|}{$S_{i}^{-}$} & Score & Rank \\
\hline B1 & 0,13187099 & 0,498562 & 0,790825 & 2 \\
\hline B2 & 0,59060601 & 0,050411 & 0,078643 & 5 \\
\hline B3 & 0,60473355 & 0,032305 & 0,050711 & 6 \\
\hline B4 & 0,05721863 & 0,60377 & 0,913435 & 1 \\
\hline B5 & 0,59513125 & 0,021382 & 0,034682 & 7 \\
\hline B6 & 0,18552861 & 0,432255 & 0,699687 & 3 \\
\hline B7 & 0,18574147 & 0,430434 & 0,698557 & 4 \\
\hline B1 & 0,39126924 & 0,40318 & 0,507496 & 3 \\
\hline B2 & 0,57698005 & 0,291482 & 0,33563 & 4 \\
\hline B3 & 0,72417838 & 0,26011 & 0,264262 & 7 \\
\hline B4 & 0,26291534 & 0,723031 & 0,733337 & 1 \\
\hline B5 & 0,59209592 & 0,275098 & 0,317228 & 5 \\
\hline B6 & 0,62485095 & 0,239192 & 0,276829 & 6 \\
\hline B7 & 0,3535213 & 0,477056 & 0,574367 & 2 \\
\hline B1 & 0,85958377 & 0,240675 & 0,218744 & 6 \\
\hline B2 & 0,76358766 & 0,510061 & 0,400472 & 2 \\
\hline B3 & 0,02049332 & 1,092898 & 0,981594 & 1 \\
\hline B4 & 0,89262428 & 0,249144 & 0,218209 & 7 \\
\hline B5 & 0,8192303 & 0,458242 & 0,35871 & 3 \\
\hline B6 & 0,93373742 & 0,499454 & 0,348491 & 4 \\
\hline B7 & 0,84013918 & 0,256555 & 0,233935 & 5 \\
\hline B1 & 0,1330372 & 0,030552 & 0,186759 & 6 \\
\hline B2 & 0,0620899 & 0,117389 & 0,654054 & 3 \\
\hline B3 & 0,04756233 & 0,14279 & 0,750136 & 2 \\
\hline B4 & 0,15488455 & 0,008293 & 0,050821 & 7 \\
\hline B5 & 0,03554483 & 0,126421 & 0,780542 & 1 \\
\hline B6 & 0,06683206 & 0,119369 & 0,641077 & 4 \\
\hline B7 & 0,12917654 & 0,031918 & 0,198131 & 5 \\
\hline B1 & 0,09600826 & 0,033208 & 0,256993 & 7 \\
\hline B2 & 0,04582924 & 0,090926 & 0,664883 & 2 \\
\hline B3 & 0,04127087 & 0,10395 & 0,715805 & 1 \\
\hline B4 & 0,07992006 & 0,055378 & 0,409305 & 5 \\
\hline B5 & 0,09566189 & 0,080598 & 0,457267 & 4 \\
\hline B7 & 0,08843417 & 0,06017 & 0,404901 & 6 \\
\hline & 0,06604035 & 0,062133 & 0,484758 & 3 \\
\hline & & & \\
\hline
\end{tabular}

When the 2014-2018 years were analyzed by the TOPSIS method as given in Table 7, it was observed that there were fluctuations between the TOPSIS performance scores of the banks. The changes of TOPSIS performance scores over the years are given below:

for 2014: $\mathrm{HB}>\mathrm{AB}>\mathrm{TVB}>\mathrm{YKB}>\mathrm{ZB}>\mathrm{GB}>\mathrm{I} \mathrm{B}$, for 2015: $\mathrm{HB}>\mathrm{YKB}>\mathrm{AB}>\mathrm{ZB}>\mathrm{I} B>\mathrm{TVB}>\mathrm{GB}$, for 2016: $\mathrm{GB}>\mathrm{ZB}>\mathrm{I} \mathrm{I}>\mathrm{TVB}>\mathrm{YKB}>\mathrm{AB}>\mathrm{HB}$, for 2017: $\mathrm{IB}>\mathrm{GB}>\mathrm{ZB}>\mathrm{TVB}>\mathrm{YKB}>\mathrm{AB}>\mathrm{HB}$ for 2018: $\mathrm{GB}>\mathrm{ZB}>\mathrm{YKB}>\mathrm{I} \mathrm{B}>\mathrm{HB}>\mathrm{TVB}>\mathrm{AB}$. 
When the 2014-2018 period is analyzed, it is determined that bank performances vary. It can be said that this change does not show a regular trend. For example; while HB ranked first on the list in 2014 and 2015, it was at the end of the list in 2016 in terms of financial performance. Moreover, while the GB bank was in the lower ranks in 2014 and 2015, it reached the upper ranks in the 2016-2018 period. This is due to the fact that the dataset includes both state and private banks. Furthermore, the political and economic crises in the country have different effects on banks. For the other banks, these fluctuations are also valid in different sizes. When financial values related to banks are taken into consideration, there is a similarity between the non-performing loans / total loans ratio and topsis performance scores.

\section{Analysis of Financial Performance of Banks by Fuzzy Topsis Method}

First, the decision matrix is created. The decision matrix created with fuzzy TOPSIS method is given in Table 8.

Table 8. Decision matrix

\begin{tabular}{|c|c|c|c|c|c|c|c|c|}
\hline Code & Year & B1 & B2 & B3 & B4 & B5 & B6 & B7 \\
\hline \multirow[t]{5}{*}{ K1 } & 2014 & 0,020628 & 0,025846 & 0,017545 & 0,017148 & 0,026439 & 0,014255 & 0,012171 \\
\hline & 2015 & 0,009143 & 0,008658 & \begin{tabular}{|l|}
0,019403 \\
\end{tabular} & 0,016561 & 0,012427 & 0,011456 & 0,014822 \\
\hline & 2016 & 0,016845 & 0,018103 & 0,018036 & 0,011142 & 0,015131 & 0,012097 & 0,012003 \\
\hline & 2017 & 0,029235 & 0,019875 & 0,021653 & 0,014133 & 0,023136 & 0,015298 & 0,013362 \\
\hline & 2018 & 0,123517 & 0,10099 & 0,116967 & 0,074753 & 0,09946 & 0,082261 & 0,104462 \\
\hline \multirow[t]{5}{*}{$\mathrm{K} 2$} & 2014 & 0,612442 & 0,569991 & 0,6095 & 0,646502 & 0,653212 & 0,659493 & 0,666317 \\
\hline & 2015 & 0,603112 & 0,61398 & 0,622403 & 0,670109 & 0,642094 & 0,672186 & 0,668306 \\
\hline & 2016 & 0,596543 & 0,649573 & 0,651203 & 0,67913 & 0,651884 & 0,689842 & 0,674419 \\
\hline & 2017 & 0,602335 & 0,686277 & 0,641483 & 0,661984 & 0,660707 & 0,676095 & 0,647669 \\
\hline & 2018 & 0,522237 & 0,654257 & 0,559398 & 0,645369 & 0,520729 & 0,643012 & 0,56928 \\
\hline \multirow[t]{5}{*}{ K3 } & 2014 & 0,018519 & 0,019251 & 0,024738 & 0,036819 & 0,015585 & 0,038089 & 0,035894 \\
\hline & 2015 & 0,02382 & 0,01689 & \begin{tabular}{|l|}
0,02782 \\
\end{tabular} & 0,031588 & 0,020356 & 0,039441 & 0,041635 \\
\hline & 2016 & 0,026394 & 0,018146 & 0,028495 & 0,032702 & 0,024339 & 0,043743 & 0,051061 \\
\hline & 2017 & 0,023812 & 0,016019 & 0,025922 & 0,03021 & 0,02257 & 0,041754 & 0,046787 \\
\hline & 2018 & 0,035394 & 0,015123 & 0,037094 & 0,026451 & 0,03845 & 0,042327 & 0,043936 \\
\hline \multirow[t]{5}{*}{ K4 } & 2014 & 0,004187 & 0,018916 & 0,006201 & 0,007593 & 0,007998 & 0,004481 & 0,0058 \\
\hline & 2015 & 0,003366 & 0,015987 & 0,012087 & 0,011183 & 0,015778 & 0,00756 & 0,012224 \\
\hline & 2016 & 0,003229 & 0,014857 & 0,011926 & 0,009998 & 0,014069 & 0,006633 & 0,010497 \\
\hline & 2017 & 0,01081 & 0,012068 & 0,01159 & 0,008304 & 0,012279 & 0,005238 & 0,00864 \\
\hline & 2018 & 0,011132 & 0,008876 & 0,010287 & 0,008109 & 0,010263 & 0,00745 & 0,008758 \\
\hline \multirow[t]{5}{*}{ K5 } & 2014 & 0,014675 & 0,017364 & 0,008959 & \begin{tabular}{|l|}
0,00529 \\
\end{tabular} & 0,010976 & 0,009323 & 0,007805 \\
\hline & 2015 & 0,010131 & 0,014585 & 0,00713 & 0,00427 & 0,011952 & 0,007618 & 0,008818 \\
\hline & 2016 & 0,009168 & 0,013164 & 0,006699 & 0,004563 & 0,011364 & 0,007042 & 0,006584 \\
\hline & 2017 & 0,009701 & \begin{tabular}{|l}
0,012727 \\
\end{tabular} & 0,007579 & 0,00505 & 0,011567 & 0,006315 & 0,00819 \\
\hline & 2018 & 0,084904 & 0,07124 & 0,103635 & 0,090044 & 0,080287 & 0,093589 & 0,148684 \\
\hline \multirow[t]{5}{*}{ K6 } & 2014 & 6,696827 & 2,200196 & 3,427497 & 0,09773 & $-0,6328$ & 0,800429 & 0,507639 \\
\hline & 2015 & 3,315724 & 3,006268 & 0,646079 & 1,279218 & 1,509432 & $-0,60555$ & 7,881935 \\
\hline & 2016 & 1,147222 & 1,343235 & $-11,1394$ & \begin{tabular}{|l|}
0,099967 \\
\end{tabular} & 2,185335 & 4,204589 & 0,509731 \\
\hline & 2017 & 0,71661 & 1,386764 & 2,45169 & 0,087448 & 9,776749 & 0,157454 & 1,574148 \\
\hline & 2018 & $-2,48684$ & 3,405254 & 10,2055 & 3,392841 & $-5,32421$ & 4,299422 & 2,888542 \\
\hline \multirow[t]{5}{*}{ K7 } & 2014 & $-0,01208$ & 0,013449 & 0,013729 & $-0,0167$ & 0,013304 & $-0,0086$ & $-0,00842$ \\
\hline & 2015 & $-0,0101$ & \begin{tabular}{|l|}
0,013375 \\
\end{tabular} & 0,014446 & $-0,01465$ & 0,012268 & 0,009583 & $-0,0137$ \\
\hline & 2016 & $-0,00944$ & 0,01443 & 0,011988 & $-0,00953$ & 0,009892 & 0,009081 & $-0,00813$ \\
\hline & 2017 & $-0,00743$ & 0,015143 & 0,015591 & $-0,00758$ & 0,012974 & 0,00999 & $-0,00625$ \\
\hline & 2018 & $-0,00095$ & $-0,00675$ & $-0,00289$ & 0,000384 & $-0,00814$ & 0,001868 & $-0,00173$ \\
\hline
\end{tabular}




\begin{tabular}{|c|c|c|c|c|c|c|c|c|}
\hline K8 & 2014 & $-0,82335$ & 0,774572 & 1,532519 & $-3,15661$ & 1,212107 & $-0,92208$ & $-1,07857$ \\
\cline { 2 - 9 } & 2015 & $-0,99728$ & 0,917024 & 2,025908 & $-3,43205$ & 1,026462 & 1,257999 & $-1,55319$ \\
\cline { 2 - 9 } & 2016 & $-1,03023$ & 1,096144 & 1,789473 & $-2,08882$ & 0,870499 & 1,289599 & $-1,23548$ \\
\cline { 2 - 9 } & 2017 & $-0,76546$ & 1,189907 & 2,0572 & $-1,50156$ & 1,121645 & 1,582006 & $-0,76284$ \\
\cline { 2 - 9 } & 2018 & $-0,08499$ & $-0,75997$ & $-0,28084$ & 0,047414 & $-0,79365$ & 0,250673 & $-0,19804$ \\
\hline K9 & 2014 & 0,033688 & 0,034761 & 0,033998 & 0,032888 & 0,03135 & 0,029399 & 0,030936 \\
\cline { 2 - 9 } & 2015 & 0,031249 & 0,0347 & 0,036334 & 0,030165 & 0,03259 & 0,029989 & 0,031049 \\
\cline { 2 - 9 } & 2016 & 0,029321 & 0,038988 & 0,039052 & 0,030058 & 0,034777 & 0,032778 & 0,030198 \\
\cline { 2 - 8 } & 2017 & 0,033367 & 0,03892 & 0,044486 & 0,025546 & 0,03645 & 0,031864 & 0,030929 \\
\cline { 2 - 8 } & 2018 & 0,041068 & 0,038558 & 0,047877 & 0,020812 & 0,034111 & 0,031455 & 0,03734 \\
\hline K10 & 2014 & 0,705968 & 0,80311 & 0,696737 & 0,743451 & 0,662617 & 0,6649 & 0,686849 \\
\cline { 2 - 8 } & 2015 & 0,707996 & 0,796347 & 0,769466 & 0,740609 & 0,738381 & 0,720244 & 0,731533 \\
\cline { 2 - 8 } & 2016 & 0,651708 & 0,810145 & 0,748349 & 0,746253 & 0,729413 & 0,735101 & 0,688532 \\
\cline { 2 - 8 } & 2017 & 0,746476 & 0,84647 & 0,84014 & 0,72688 & 0,796714 & 0,725502 & 0,726843 \\
\cline { 2 - 8 } & 2018 & 0,880241 & 1,117912 & 0,867261 & 0,905804 & 1,091064 & 0,790196 & 0,888478 \\
\hline
\end{tabular}

In the next stage, the normalization of the decision matrix is created. Then weighted fuzzy normalized decision matrix is created with the use of weights. The criterion weights are determined by equation 11. The weight values of ratios are given in Table 9 while the weighted fuzzy normalized decision matrix is given in Table 10.

Table 9. Weight values of ratios

\begin{tabular}{|l|r|}
\hline Rate & Weight \\
\hline EQUITY / TOTAL ASSETS & 0,19 \\
\hline TOTAL LOANS / TOTAL ASSETS & 0,1 \\
\hline NON-PERFORMING LOAN/TOTAL LOANS & 0,01 \\
\hline FIXED ASSET / TOTAL ASSETS & 0,1 \\
\hline LIQUID ASSET / TOTAL ASSET & 0,2016 \\
\hline LIQUID ASSET / SHORT TERM LIABILITIES & 0,0084 \\
\hline NET PROFIT FOR THE PERIOD / TOTAL ASSETS & 0,02 \\
\hline NET PROFIT FOR THE PERIOD / TOTAL EQUITY & 0,17 \\
\hline NET INTEREST INCOME / TOTAL ASSET & 0,19 \\
\hline NET INTEREST INCOME / TOTAL OPERATING INCOME & 0,01 \\
\hline TOTAL & 1 \\
\hline
\end{tabular}

Table 10. Weighted fuzzy normalized decision matrix

\begin{tabular}{|c|r|l|r|r|l|r|r|}
\hline Code & B1 & B2 & B3 & B4 & B5 & B6 & B7 \\
\hline K1 & 0,089537 & 0,084787 & 0,126085 & 0,091854 & 0,121693 & 0,099421 & 0,086842 \\
\cline { 2 - 9 } & 0,198646 & 0,186262 & 0,206509 & 0,152297 & 0,193465 & 0,141889 & 0,15153 \\
\cline { 2 - 9 } & 0,19 & 0,19 & 0,19 & 0,16217 & 0,19 & 0,12697 & 0,160689 \\
\hline \multirow{3}{*}{ K2 } & 0,079821 & 0,085543 & 0,085501 & 0,09646 & 0,079591 & 0,098281 & 0,087012 \\
\cline { 2 - 9 } & 0,087141 & 0,094209 & 0,091488 & 0,098053 & 0,092784 & 0,099155 & 0,095715 \\
\cline { 2 - 9 } & 0,091915 & 0,1 & 0,094399 & 0,099691 & 0,098033 & 0,1 & 0,1 \\
\hline K3 & 0,004862 & 0,003424 & 0,00554 & 0,00602 & 0,004092 & 0,008567 & 0,009424 \\
\cline { 2 - 8 } & 0,005779 & 0,003906 & 0,006548 & 0,007227 & 0,005465 & 0,00932 & 0,009885 \\
\cline { 2 - 8 } & 0,008056 & 0,005054 & 0,008443 & 0,009667 & 0,008751 & 0,01 & 0,01 \\
\hline K4 & 0,021056 & 0,079735 & 0,032779 & 0,04014 & 0,042284 & 0,02369 & 0,030663 \\
\cline { 2 - 8 } & 0,050594 & 0,095604 & 0,07509 & 0,063572 & 0,085573 & 0,045043 & 0,065364 \\
\cline { 2 - 8 } & 0,1 & 0,1 & 0,094389 & 0,072838 & 0,1 & 0,066924 & 0,078676 \\
\hline & 0,115121 & 0,096594 & 0,09856 & 0,059016 & 0,108861 & 0,100032 & 0,090624 \\
\hline
\end{tabular}




\begin{tabular}{|c|r|r|r|r|r|r|r|}
\hline K5 & 0,143923 & 0,180599 & 0,113147 & 0,078478 & 0,151752 & 0,109662 & 0,128935 \\
\cline { 2 - 9 } & 0,170382 & 0,2016 & 0,140519 & 0,122091 & 0,183232 & 0,126898 & 0,2016 \\
\hline \multirow{3}{*}{ K6 } & $-0,00205$ & 0,001191 & $-0,02225$ & $7,51 \mathrm{E}-05$ & $-0,00438$ & $-0,00065$ & 0,000637 \\
\cline { 2 - 9 } & 0,002559 & 0,002528 & $-0,00135$ & 0,000911 & 0,00184 & 0,002487 & 0,002757 \\
\cline { 2 - 9 } & 0,0084 & 0,003204 & 0,0084 & 0,002793 & 0,0084 & 0,0084 & 0,0084 \\
\hline \multirow{3}{*}{ K7 } & $-0,0176$ & $-0,07224$ & $-0,03094$ & $-0,02432$ & $-0,08722$ & $-0,01252$ & $-0,01896$ \\
\cline { 2 - 9 } & $-0,01287$ & 0,001059 & 0,009135 & $-0,01269$ & $-0,0041$ & 0,00923 & $-0,01382$ \\
\cline { 2 - 8 } & $-0,00953$ & 0,02 & 0,02 & 0,004117 & 0,019381 & 0,02 & $-0,00801$ \\
\hline K8 & $-0,09787$ & $-0,51539$ & $-0,19046$ & $-0,35016$ & $-0,53823$ & $-0,10229$ & $-0,1343$ \\
\cline { 2 - 8 } & $-0,07876$ & $-0,03001$ & 0,097908 & $-0,1857$ & $-0,02845$ & 0,085304 & $-0,11294$ \\
\cline { 2 - 8 } & $-0,05764$ & 0,104134 & 0,17 & 0,032155 & 0,134457 & 0,17 & $-0,06304$ \\
\hline K9 & 0,14251 & 0,153018 & 0,185827 & 0,082592 & 0,135369 & 0,124831 & 0,132099 \\
\cline { 2 - 8 } & 0,159137 & 0,176077 & 0,189165 & 0,135088 & 0,160404 & 0,147582 & 0,151733 \\
\cline { 2 - 8 } & 0,184136 & 0,19 & 0,19 & 0,179762 & 0,171357 & 0,160693 & 0,169095 \\
\hline K10 & 0,007874 & 0,01 & 0,007758 & 0,008103 & 0,008251 & 0,007068 & 0,007948 \\
\cline { 2 - 8 } & 0,008484 & 0,01 & 0,009052 & 0,008892 & 0,00914 & 0,008407 & 0,008554 \\
\cline { 2 - 8 } & 0,008891 & 0,01 & 0,009925 & 0,0093 & 0,00976 & 0,009074 & 0,009186 \\
\hline
\end{tabular}

After calculating the weighted normalized fuzzy decision matrix, the fuzzy positive ideal solution and fuzzy negative ideal solution are calculated and the distance to the positive and negative ideal solution points for each alternative is calculated. The results are given in Table 11.

Table 11. Total value of distances to positive and negative ideal solution score

\begin{tabular}{|r|r|}
\hline \multicolumn{1}{|c|}{$d_{i}^{*}$} & $d_{i}^{-}$ \\
\hline 9,289132 & 0,791839 \\
\hline 9,196336 & 0,899704 \\
\hline 9,230456 & 0,846162 \\
\hline 9,285832 & 0,774616 \\
\hline 9,225778 & 0,857058 \\
\hline 9,34665 & 0,699068 \\
\hline 9,301128 & 0,758928 \\
\hline
\end{tabular}

Finally, the proximity coefficient is calculated for each bank

$$
\begin{aligned}
& C C_{B 1}=\frac{0,74588}{9,326003+0,74588}=0,074056 \\
& C C_{B 2}=0,08882 \\
& C C_{B 3}=0,080792 \\
& C C_{B 4}=0,074761 \\
& C C_{B 5}=0,083301 \\
& C C_{B 6}=0,066116 \\
& C C_{B 7}=0,07127 .
\end{aligned}
$$

The study of banks' financial results in 2014-2018 using Fuzzy TOPSIS method reveals ZB, IB and GB banks are the top three most profitable banks. The YKB has been found to be the bank with the worst financial return. The average bank results between these years were found to be 0.079 .

The output of HB, TVB and YKB banks for the period 2014-2018 was shown to be below average. The three largest banks that performed better than their average performance were observed.

The ranking of banks' financial performances is: $\mathrm{ZB}>\mathrm{IB}>\mathrm{GB}>\mathrm{HB}>\mathrm{AB}>\mathrm{TVB}>\mathrm{YKB}$. 
The most important parameters were asset ratio and liquidity ratio when the parameter weights were compared. Based on these parameters, during this time ZB and IB banks performed better. Total assets have been defined as a distinguishing criterion among the criteria.

\section{RESULTS AND DISCUSSION}

Banks, which form an important part of the money and financial markets, are the commercial institutions that make capital, money and credit transactions. A strong and profitable banking system contributes to financial continuity. Therefore, the performance of the banking system is important for each production and service unit in the economy. Banks' performance analysis and evaluation of the results enable them to work effectively and efficiently. In this study, based on relevant criteria, the first seven banks were ranked in total assets according to reports received from The Banks Association of Turkey for 2014-2018 financial year and a performance evaluation was done by using the TOPSIS and Fuzzy TOPSIS method. Firstly, the findings were tested using TOPSIS method. The standardization process was first applied to the data during the TOPSIS evaluation process. Afterwards, by increasing the weighted standardisation matrix, the corresponding parameters were obtained.

Fuzzy TOPSIS method is a method that gives very robust results in a highly uncertain environment among multi-criteria decision-making methods. The 5-year success ranking of the banks was analyzed in the Fuzzy TOPSIS method. The normalization process was primarily carried out on data from 2014-2018 during the assessment using the Fuzzy TOPSIS method. Then, the fuzzy TOPSIS application was carried out using triangular fuzzy numbers by the data. At the conclusion of the assessment conducted on Fuzzy TOPSIS, ZB, IB and GB banks were among the three best-performing banks. The fuzzy TOPSIS scores of these three banks were found to be above average.

As a result, financial performances of banks were analyzed with different statistical methods. However, studies on this subject using Fuzzy Topsis method are limited. Moreover, in this study, a comparison of the two methods was made. When findings from TOPSIS and Fuzzy TOPSIS were compared, different results were found for each method. Financial performance could be evaluated annually in TOPSIS method. Thus, financial performance changes can be compared on a yearly basis. However, in the fuzzy TOPSIS method, only an entire period can be assesed.

Considering the results of the study, it can be said that both methods give meaningful results when previous studies are considered. However, the difference in approach in terms of the period evaluated by the two methods does not allow to make a one-to-one comparison of the banks' financial performance.

Financial analysis of the banks can be done in many ways. Some of these are CAMLES, DEA, AHP, MOORS, WASPAS, COPRAS, TOPSIS. However, in today's conditions, fuzzy methods are being used in financial performance analysis with increasing uncertainty and competition environments.

One way for banks to adapt to changing conditions and to cope with crisis periods is to analyze financial ratios correctly. This is also vital condition for growth. That is, the accuracy and interpretation of these ratio analysis results, which will be considered as an early warning system, gain importance day by day. Finally, the approaches made using different methods and the importance of comparing them should be taken into consideration in the analysis process.

The next objective is to evaluate the financial performance of banks by expanding the dataset used and applying other methods. The method considered in this regard is Data Envelopment Analysis. Thus, it will be seen what difference this method, which was applied to studies previously conducted by using other variables, will make based on the asset size of the banks. Another study subject will be to perform financial performance of banks by grouping them out of asset size and using different financial ratios by applying TOPSIS, Fuzzy TOPSIS and Data Envelopment Analysis.

\section{CONFLICTS OF INTEREST}

No conflict of interest was declared by the author. 


\section{REFERENCES}

[1] Parker, C., Performance measurement. Work Study, 49(2): 63-66, (2000).

[2] Atkinson, A., Waterhouse, J. H., Wells, R. B., "A Stakeholder Approach to Strategic Performance Measurement", Sloan Management Review, 38:25-37, (1997).

[3] Tozum, H., "Performance evaluation of banks", Active: Journal of Banking and Finance, 27:1-9, (2002).

[4] Li, S., Liu, F., Liu, S., Whitmore, G. A., "Comparative Performance of Chinese Commercial Banks, Findings and Policy Implications", Reviews of Quantities Finance and Accounting, 16:149-170, (2001).

[5] Guven, S., Persentili, E., "A Linear Programming Model for Bank Balancesheet Management", Omega, 25:449-459, (1997).

[6] Zopounidis, C., Pouliezos, A., Yannacopoulo, D., "Designing Adds for The Assessment of Company Performance and Viability", Computer Science in Economics and Management, 5:4156, (1992).

[7] Siskos Y., Zopounidis C., Pouliezos A., "An Integrated DSS for Financing Firms by an Industrial Development Bank in Greece”, Decision Support Systems, 12:151-168, (1994).

[8] Ecer, F., "Türkiye' deki Özel Bankaların Finansal Performanslarının Karşılaştırılması: 2008-2011 Dönemi”, Abant İzzet Baysal Üniversitesi, Sosyal Bilimler Enstitüsü Dergisi, 13 (2): 171- 189, (2013).

[9] Dincer, H., Gencer, G., Orhan, N., Sahinbas, K., "A Performance Evaluation of the Turkish Banking Sector After the Global Crisis via CAMELS Ratios", Procedia Social and Behavioral Sciences, 24:1530-1545, (2011).

[10] Guneysu, Y., Er, B. ve Ar, I.M., “Türkiye'deki Ticari Bankaların Performanslarının AHS ve GIA Yöntemleri ile İncelenmesi”, Karadeniz Teknik Üniversitesi Sosyal Bilimler Dergisi, 9: 71-93, (2015).

[11] Tezergil, S.A., "Vikor Yöntemi ile Türk Bankac1lık Sektörünün Performans Analizi”, Marmara Üniversitesi İktisadi ve İdari Bilimler Dergisi, 38 (1): 357-373, (2016).

[12] Altunoz, U., Bankaların finansal performanslarının bulanık MOORA ve bulanık AHP yöntemleri ile analizi: Türk bankaları deneyimi. Route Educational and Social Science Journal, 4(4): 116132, (2017).

[13] Gunay, A. ve Gunay, B., Türkiye'deki Mevduat Bankalarının Etkinlik Ölçümü ve Performanslarının Çok Kriterli Karar Verme Yöntemleriyle Değerlendirilmesi. Uluslararası Sosyal Araştırmalar Dergisi, 12(62): 1316- 1325, (2019).

[14] Mittal, M., Dhade, A., "Awareness and Perception of CAMEL Rating Across Banks: Some Survey Evidence", ICFAI Journal of Bank Management, 8:51-63, (2009).

[15] Demir, Y., Astarcioglu, M., "Determining Bank Performance via Financial Prediction: An Application in ISE. Süleyman Demirel University", Journal of Business Administration and Economics Faculty, 12(1):273-292, (2007). 
[16] Mercan, M., Reisman, A., Yolalan, R., Emel, A. B., "The Effect of Scale And Mode of Ownership on The Financial Performance of Turkish Banking Sector: Result of a DEA-based analysis", Socio-Economic Planning Sciences, 37:185-202, (2003).

[17] Lin, X., Zhang, Y., "Bank Ownership Reform and Bank Performance in China", Journal of Banking\&Finance, 33(1):20-29, (2009).

[18] Bauer, P. W., Berger, A. N., Ferrier, G. D., Humphrey, D. B., "Consistency Conditions for Regulatory Analysis of Financial Institutions: A Comparison of Frontier Efficiency Methods", Journal of Economic and Business, 50(2):85-114, (1998).

[19] Parkan, C., Wu, M., "Measurement of the Performance of an Investment Bank Using the Operational Competitiveness Rating Procedure", Omega, 27:210-217, (1999).

[20] Denizer, C. A., Dinc, M.,Tarimcilar, M., "Measuring Banking Efficiency in The Pre- And PostLiberalization Environment: Evidence from the Turkish Banking System (English)", Policy, Research Working Paper; no. WPS 2476, Washington, DC: World Bank, (2000).

[21] Isik, I., Uysal, D., Meleke, U., "Post-Entry Performance of De Novo Banks in Turkey", In 10th Annual Conference of the ERF, (2003).

[22] Demirguc-Kunt, A., Huizinga, H., "Determinants of Commercial Bank Interest Margins and Profitability: Some International Evidence", The World Bank Economic Review, 13:379-408, (1999).

[23] Thanassoulis, E., Boussofiane, A., Dyson, R. G., "A Comparison of Data Envelopment Analysis and Ratio Analysis as Tools for Performance Assessment", Omega, 24:229-244, (1995).

[24] Lee, H., Kwak, W., Han, I., "Developing a Business Performance Evaluation System: An Analytic Hierarchical Model”, The Engineering Economist, 40:343-357, (1995).

[25] Suwignjo, P., Bittici, U. S., Carrie, A. S., "Quantative Models for Performance Measurement System (QMPMS)", International Journal of Operation Production Management, 64:231-241, (2000).

[26] Wang, G., Huang, S., Dismukes, J., "Product-Driven Supply Chain Selection Using Integrated Multi-Criteria Decision-Making Methodology", International Journal of Operations and Production Management, 91:1-15, (2004).

[27] Frei, F. X., Harker, P. T., "Measuring Aggregate Process Performance Using AHP”, European Journal of Operational Research, 116:436-442, (1999).

[28] Yurdakul, M., Ic, Y.T., "AHP Approach in the Credit Evaluation of the Manufacturing Firms in Turkey”, International Journal of Production Economics, 88(3):269-289, (2004).

[29] Albayrak, E., Erensal, Y. C., "A Study Bank Selection Decision in Turkey Using The Extended Fuzzy AHP Method", In 35th International Conference on Computers and Industrial Engineering, Istanbul, Turkey, (2005).

[30] Ta, H. P., Kar, Y. H., "A Study of Bank Selection Decisions in Singapore Using the Analytical Hierarchy Process", The International Journal of Bank Marketing, 18:170-180, (2000). 
[31] Che, Z.H., Wang, H.S., Chuang, C. L., “A Fuzzy AHP and DEA Approach for Marketing Bank Loan Decisions for Small and Medium Enterprises in Taiwan", Expert Systems With Applications, 37:7189-7199, (2010).

[32] Shaverdi, M., Akbari, M., Tafti, S. F., "Combining Fuzzy MCDM with BSC Approach in Performance Evaluation of Iranian Private Banking Sector", Advances in Fuzzy Systems, 2011:112, (2011).

[33] Secme, N.Y., Bayrakdaroglu, A., Kahraman, C., "Fuzzy Performance Evaluation in Turkish Banking Sector Using Analytic Hierarchy Process and TOPSIS", Expert Systems with Applications, 36(9):11699- 11709, (2009).

[34] Chen, S. J., Hwang, C. L., "Fuzzy Multiple Attribute Decision Making Methods and Application", Lecture Notes in Economics and Mathematical Systems, vol 375, Springer, Berlin, Heidelberg, (1992).

[35] Hwang, C. L., Yoon, K., "Multiple Attribute Decision Making: Methods and Application", New York: Springer, (1981).

[36] Yurdakul, M., Ic, Y.T., "Türk Otomotiv Firmalarının Performans Ölçümü ve Analizine Yönelik TOPSIS Yöntemi Kullanan Bir Örnek Çalışma”, Gazi Üniversitesi Mühendislik ve Mimarlık Fakültesi Dergisi, 18(1):1-13, (2003).

[37] Eleren, A., Karagul, M., "1986-2006 Türkiye Ekonomisinin Performans Değerlendirmesi", Yönetim ve Ekonomi: Celal Bayar Üniversitesi İktisadi ve İdari Bilimler Fakültesi Dergisi, 15(1):1-14. Retrieved from https://dergipark.org.tr/tr/pub/yonveek/issue/13688/165655, (2008).

[38] Sakthivel, G. Ilangkumaran, M. ve Gaikwad, A., "A Hybrid Multi-Criteria Decision Modeling Approach for the Best Biodiesel Blend Selection Based on ANP-TOPSIS Analysis", Ain Shams Engineering Journal, 6(1):239-256. doi:10.1016/j.asej.2014.08.003, (2015).

[39] Demireli, E., "TOPSIS Çok Kriterli Karar Verme Sistemi: Türkiye'deki Kamu Bankaları Üzerine Bir Uygulama", Girişimcilik ve Kalkınma Dergisi, 5:1, (2010).

[40] Alp, S., Engin, T., "Trafik Kazalarının Nedenleri ve Sonuçları Arasındaki İlişkinin, TOPSIS ve AHP Yöntemleri Kullanılarak Analizi ve Değerlendirilmesi”, İstanbul Ticaret Üniversitesi Fen Bilimleri Dergisi, 10(19):65-87, (2011).

[41] Jadidi, O., Hong, T.S., Firouzi F., Yusuf R.M., Zulkifli N., "TOPSIS and Fuzzy Multi Objective Model Integration for Supplier Selection Problem", Journal of Achievements in Materials and Manufacturing Engineering, 31(2):762-769, (2008).

[42] Ustasuleyman, T., "Bankacılık Sektöründe Hizmet Kalitesinin Değerlendirilmesi: AHS-TOPSIS Yöntemi”, Bankac1lar Dergisi, 69:33-43, (2009).

[43] Mahmoodzadeh, S. Shahrabi, J. Pariazar, M. ve Zaeri, M.S., "Project Selection by Using Fuzzy AHP and TOPSIS Technique", International Journal of Social, Education, Economics and Management Engineering, 1(6):301-306, (2007).

[44] Korkmaz, M., "Orman İşletmelerinde İktisadilik Düzeyinin TOPSIS Yöntemi ile Analizi”, SDÜ Orman Fakültesi Dergisi / SDU Faculty of Forestry Journals, 13:14-20, (2012).

[45] Zadeh, L. A., "Fuzzy Sets", Information and Control, 8:338-353, (1965). 
[46] Vatansever, K., "Use of Fuzzy TOPSIS Method in Supplier Selection Decision and an Application”, Anadolu University Journal of Social Sciences, 13(3):155-168, (2013).

[47] Lee, H. S., "A Fuzzy Multi-Criteria Decision Making Model for The Selection of the Distribution Center”. Lecture notes in artificial intelligence, 3612:1290-1299, (2005).

[48] Chang, D. Y., "Applications of the Extent Analysis Method on Fuzzy AHP”, European Journal of Operational Research, 95(3):649-655, (1996).

[49] Chen, C. T., "Extensions to the TOPSIS for Group Decision-Making Under Fuzzy Environment", Fuzzy Sets and Systems, 114:1-9, (2000).

[50] Unal, O. F., “Analitik Hiyerarşi Prosesi ve Personel Seçimi Alanında Uygulamaları”, Journal of Alanya Faculty of Business / Alanya İşletme Fakültesi Dergisi, 3(2): 1-20, (2011).

[51] Jahanshahloo, G.R., Hosseinzadeh,F., Izadikhah, M., "Extension of the TOPSIS Method for Decision Making Problems with Fuzzy Data, Applied Mathematics and Computation, 181:15441551, (2006).

[52] Chen, C.T., Lin, C.T., Hwang, S.F., "A Fuzzy Approach for Supplier Evaluation and Selection in Supply Chain Management”, International Journal of Production Economics, 102:289-301, (2006). 